\title{
A RIVER TERRACE SOIL CHRONOSEQUENCE OF THE PAKUA TABLELAND IN CENTRAL TAIWAN
}

\author{
Hens Tsai', Wen-Shu Huans', Zens-Yei Hseu ${ }^{2}$, and Zuens-Sans $\mathrm{Chen}^{3}$
}

Soils science and fluvial geomorphology meet on the subject about flights of river terraces whose treads rise like stairs above active channels. The Pakua tableland in central Taiwan consists of widely unpaired terraces, including six levels in altitude formed by successive river incision. The terraces serve as geomorphic markers to gauge the differential or absolute deformation of the land surface but such application is hampered by the absence of well-documented ages. Six representative soil pedons were selected from the six levels of terraces in the tableland (from the highest pedon PK-1 to lowest pedon PK-6) to characterize the soil properties in a chronosequence and to relate the pedogenic processes in the major terraces to the formation and evolution of the landscape in the study area. The soil morphological, physical, and chemical properties as well as the clay mineral variation showed that pedogenic intensity is strongly dependent on the terrace levels with varying formation age. The soils can be divided into three domains as Hapludox for pedon PK-1, Paleudult (or Hapludult) for pedons PK-2, PK-3, PK-4, and PK-5, and Dystrudept for pedon PK-6, based on Soil Taxonomy. The degree of soil development increases with altitude in a sequence from PK-1 to PK-6 forming a postincisive type of soil chronosequence in accord with the evolution of the geomorphic surface by successive river incision in the study area. Based on the crystallinity ratios of free iron, the soils give an estimated age of 40-400 ka for the river terraces of the tableland. (Soil Science 2006;171:167-179)

Key words: Chronosequence, pedogenesis, micromorphology, river terrace, soil classification.

$\mathbf{M}$ OST soil properties are time-dependent variables, which can be used as indicators of the duration of pedogenesis (Jenny, 1941). For instance, Muhs (1982) found that solum thickness increased linearly with time and soil structure changed from prismatic to mixed prismatic and angular blocky to exclusively angular blocky with increasing age of geomorphic surface. Bockheim

\footnotetext{
'Department of Geography, National Chanshua University of Education, Chanshua 50018, Taiwan.

2Department of Environmental Science and Engineering, National Pingtuns University of Science and Technology, Pingtuns 91201, Taiwan. Dr. Zens-Yei Hseu is correspondins author. E-mail: zyhseu@mail.npust.edu.tw

${ }^{3}$ Department of Agricultural Chemistry, National Taiwan University, Taipei 10617, Taiwan.

Received May 3, 2005; accepted Sept. 8, 2005.

DOI: 10.1097/01.ss.0000187376.76767.21
}

et al. (1996) found that the primary age-related trends in soil chronosequences on the marine terraces in southwestern Oregon include an increase in (i) the relative abundance of silt and clay, (ii) the ratio of quartz to feldspars in the very fine sand fraction, and (iii) the amounts of dithionite-extractable $\mathrm{Fe}$ and $\mathrm{Al}$ and crystalline forms of $\mathrm{Fe}$ in the profile. Some soils show agerelated trends in their soil order classification according to Soil Taxonomy on the marine terraces in the United States (Markewich and Pavich, 1991). In the Reefton area of New Zealand, a sequence of dated river terraces has produced a chronosequence of soils ranging from Dystric Fluvial on the youngest surface, through Dystric Cambisols on middle terraces, to Gleyic Podzols on the higher terraces (Dawson et al., 1991). Arduino et al. (1986) showed that the ratio $\mathrm{Fe}_{\mathrm{d}} / \mathrm{Fe}_{\mathrm{t}}$ increased from the youngest to 
the oldest pedons in a chronosequence from northern Italy. McFadden and Hendricks (1985) found that pedogenic Fe oxides and their crystallinity increased with soil age for soils formed on fluvial sediments in southern California.

The island of Taiwan has experienced mountain building since about $5 \mathrm{Ma}$ and is still active until the present time (Angelier, 1986; Ho, 1988; Tsai, 1986). River terraces are one of the most prominent geomorphic features on the land surface serving as geomorphic marker to gauge the differential or absolute surface deformation $(\mathrm{Ku}, 1963)$. However, such use of river terraces is often hampered by the absence of welldocumented ages for the deformed or partially preserved surfaces (Tsai and Sung, 2003). Bull (1990) indicated that the subjects of soil science and fluvial geomorphology meet on the study on river terraces. As the rivers downcut to new base levels, the old floodplains are suspended above the channels, resulting in varying ages of terrace levels. Consequently, the soils form a chronosequence ranging from younger soils in the lower portion to older in the higher terraces. Thus, knowledge about soil chronosequences and chronofunctions is a valuable tool not only to understand the rate and direction of pedogenic change (Dorronsoro and Alonso, 1994; Muhs, 1982; Shaw et al., 2003), but also to date or correlate a range of Quaternary landform successions (Birkeland, 1984; Leigh, 1996; Mulcahy and Churchward, 1973).

The Pakua tableland defines a deformation front of the fold-and-thrust belt in central Taiwan due to tectonic compression (Delcaillau et al., 1998; Lee et al., 1996). There is a series of widely unpaired river terraces developed in the south of the tableland. They are divided into as many as six altitudinal levels. A soil chronosequence consists of genetically related suites of soils of varying age that evolved under similar conditions of vegetation, topography, and climate (Jenny, 1941). The surface deposits of these river terraces may form a soil chronosequence because they have comparable soilforming factors except the age of the deposit. However, the identification of a particular set of soil properties that are consistently indicative of soil development is needed. Therefore, the objectives of this study were (i) to characterize the soil properties along a chronosequence of the terraces, (ii) to relate the pedogenic processes to the major terraces of Pakua tableland, and (iii) to evaluate the formation and evolution of the river terraces in the study area.

\section{MATERIALS AND METHODS}

\section{Geographic Setting}

The Pakua tableland, about $30 \mathrm{~km}$ long and 5-10 km wide, with summit elevations reach 440 above sea level, is located between the Holocene coastal plain to the west and the Quaternary Taichung basin to the east. The southern part of the tableland seems to have been deposited and incised as river terraces by the Choushui River and its tributaries (Shih and Yang, 1985) (Fig. 1A). These wide and unpaired terraces can be divided into six levels in altitude (Figs. 1B and C). All the terraces in the study area have red soil (7.5YR or redder in hues) and/or gravels, designated as "lateritic terraces" by Lin (1957), and have not yet been dated. The underlying coarse conglomerate deposits with thin sandstone or siltstone layers of the upper Tokoshan formation represent the molasse deposits of the Plio-Pleistocene Taiwan mountain building (Ho, 1988). Based on present knowledge, the terraces covered by red soils in Taiwan are dated before the $\mathrm{C}^{14}$ age of $30 \mathrm{ka}$ (Chen and Liu, 1991; Ota et al., 2002). If the soil formation began shortly after each terrace was formed, the degree soil development may indicate the age of the river terraces in the area. In this study, six representative pedons were selected from the river terraces and labeled as terraces in the order of descending altitude, with PK-1 as the highest and PK-6 the lowest (Fig. 1). All the pedons were sampled on the surface ranged from $1 \%$ to $5 \%$ in slope.

High temperature and humidity, massive rainfall, and tropical monsoon in summer characterize the climate of the study area. The annual rainfall is about $2500 \mathrm{~mm}$ and most of it falls from May to September. The East Asian monsoon system has fluctuated significantly from a strengthened winter monsoon during the last glaciation (25000-12000 years B.P.) through a moderate to weak winter and summer monsoons during the deglaciation (1200010000 years B.P.) to an enhanced summer monsoon in the Holocene (Huang et al., 1997). Palynological study in Taiwan shows a warm event that lasted several hundred years from about cal $2 \mathrm{ka}$, followed a cool-dry interval from about cal 3.7-2.0 ka. A warmer annual temperature of $1-2{ }^{\circ} \mathrm{C}$ and relatively higher precipitation during the warm interval compared with the cool-dry interval is indicated (Liew and Hsieh, 2000). According to the present climatic environment, the soil-moisture 


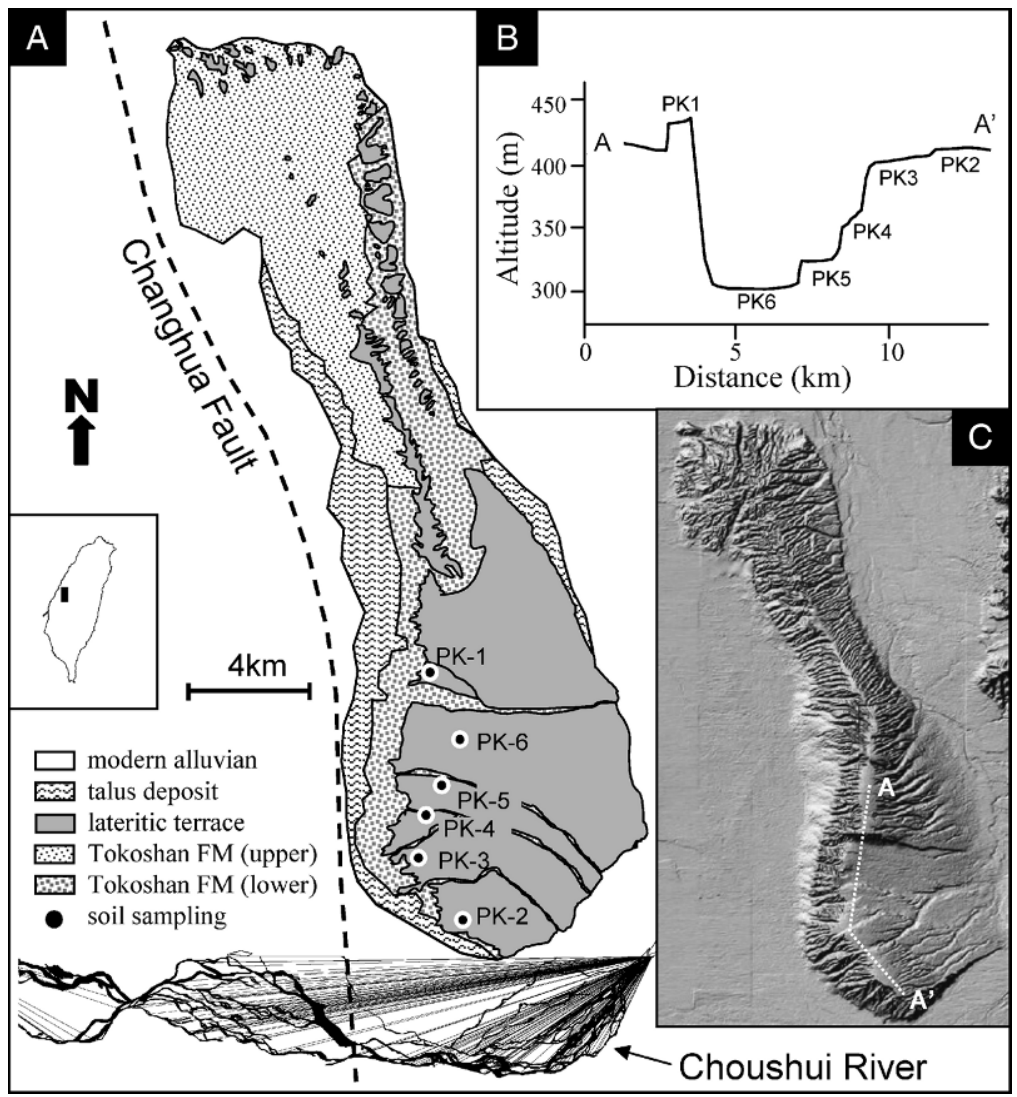

Fig. 1. The general geology and the distribution of terraces on the Pakua tableland.

regime is udic and the soil temperature regime is hyperthermic. The sub-tropical broad-leaved evergreen forests are the dominant vegetations in this area. The major land use in the study area is agricultural production involving bamboo, pineapple, tea, and lichee orchard.

\section{Physical and Chemical Analyses}

Soil morphological characteristics were described based on the U.S. Soil Survey Manual (Soil Survey Staff, 1993). Soil samples were collected from each horizon of the profiles for physical and chemical analyses. For micromorphological examination, Kubiena boxes were used to collect undisturbed soil blocks from all horizons in the field. After air drying, vertically oriented thin sections with a thickness of $30 \mu \mathrm{m}$ were prepared by Spectrum Petrographics, Inc., Oregon, USA, which were then examined under a polarized microscope and described according to the terminology of Bullock et al. (1985).

Particle size distribution was determined by the pipette method (Gee and Bauder, 1986). The
$\mathrm{pH}$ of air-dried samples $(<2 \mathrm{~mm})$ was determined on a mixture of soil/deionized water $(1: 1)$ by glass electrode (McLean, 1982). Organic carbon (OC) content was measured by the Walkley-Black wet oxidation method (Nelson and Sommers, 1982). Cation exchange capacity and exchangeable bases were measured with the ammonium acetate method (pH 7.0) (Rhoades, 1982). Exchangeable $\mathrm{Al}$ was extracted by $1 \mathrm{~N}$ of $\mathrm{KCl}$ (Thomas, 1982). Total $\mathrm{Fe}$ and $\mathrm{Al}$ were determined by the Reisenauer (1982) method. Free $\mathrm{Fe}\left(\mathrm{Fe}_{\mathrm{d}}\right)$ and $\mathrm{Al}$ $\left(\mathrm{Al}_{\mathrm{d}}\right)$ were extracted by the dithionite-citratebicarbonate (DCB) method (Mehra and Jackson, 1960). Amorphous $\mathrm{Fe}\left(\mathrm{Fe}_{\mathrm{o}}\right)$ and $\mathrm{Al}\left(\mathrm{Al}_{\mathrm{o}}\right)$ were extracted by $0.2 \mathrm{M}$ of ammonium oxalate $(\mathrm{pH}$ 3.0) (McKeague and Day, 1966). All the metals were determined by atomic absorption spectrometry (Hitachi Z-8100 Type, Japan).

\section{X-ray Diffraction of the Clay Mineral}

Air-dried samples were pretreated with 30\% $\mathrm{H}_{2} \mathrm{O}_{2}$ to remove the organic matter and then subjected to DCB treatment to remove the oxide 


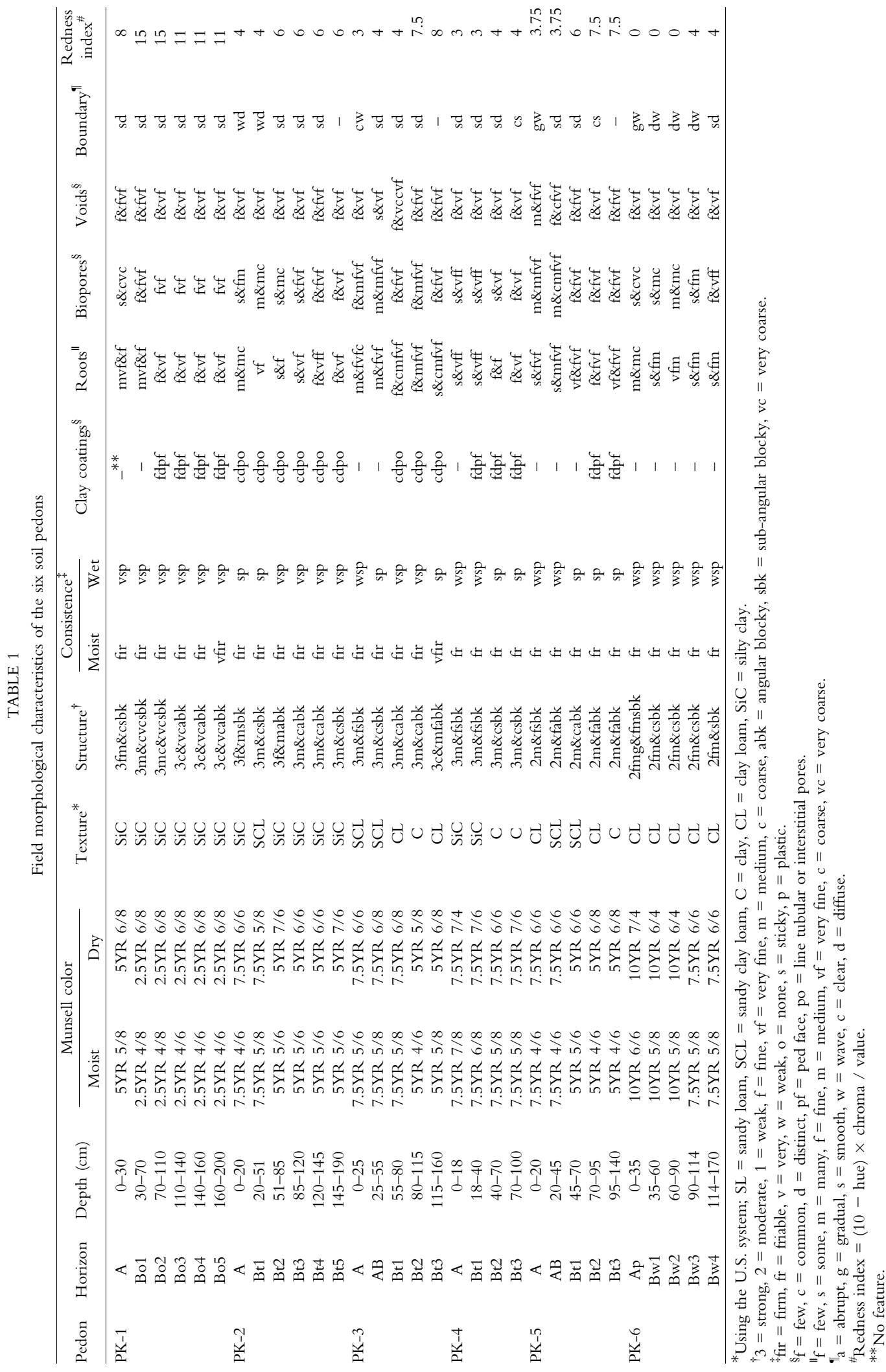


coatings. The clay fraction was separated by the pipette method (Gee and Bauder, 1986). X-ray diffraction (XRD) analysis was performed on the oriented $\mathrm{K}$-saturated and Mg-saturated clay samples. The objective of treating the clay with $6 \mathrm{~N}$ $\mathrm{HCl}$ was to destroy the chlorite structure and to easily identify the vermiculite content (Chen, 1977). Expansion properties of the Mg-saturated samples were determined by ethylene glycol solvated at $65{ }^{\circ} \mathrm{C}$ for $24 \mathrm{~h}$. The $\mathrm{K}$-saturated samples were further subjected to successive heat treatments of 110,350 , and $550{ }^{\circ} \mathrm{C}$ for $2 \mathrm{~h}$. The oriented clays were examined with an X-ray diffractometer (Rigaku Rint 2000 Type, Japan) and $\mathrm{Ni}$-filtered $\mathrm{Cu}-\mathrm{K} \alpha$ radiation generated at 30 $\mathrm{kV}$ and $10 \mathrm{~mA}$. The XRD patterns were recorded ranging from 3 to 45 degrees $(2 \theta)$ with a scanning speed of 0.5 degree $(2 \theta) / \mathrm{min}$. The identification and semiquantitative determination of the clay minerals were based on the difference of reflection patterns from the $\mathrm{K}$-saturated, $\mathrm{Mg}$ saturated, glycolated, heated, and air-dried samples (Brindley, 1980; Brown and Brindley, 1980).

\section{RESULTS AND DISCUSSION}

Field Morphology and Micromorphology

Weathering and pedogenesis are primary processes in landscape development. Depth of oxidation is the most easily determined property of weathering associated with the release of iron from silicate minerals (Markewich and Pavich, 1991). In this study, we observed that soil morphology changes with increasing age of river terrace. Throughout the Pakua tableland, pedon PK-1 on the oldest terrace level shows the most reddish hues of Munsell soil color, whereas the least can be found in pedon PK-6. For example, the oxic (Bo) horizons (Fig. 2A) of pedon PK-1 have hues of 2.5YR that are much redder than those in the cambic horizons (Bw) of pedon PK-6. As a whole, the redness index decreases with the decreasing order of terrace level (Table 1). Fine textures of the soils are reflected in their structure and consistence. Development of structure and degree of stickiness and plasticity, as well as the abundance of clay coating, increase with soil age in the river terrace. Strongly coarse angular and sub-angular blocky structures are generally found in the older pedons, whereas moderately finer ones can be observed in the younger pedons. High clay content of the soils is also associated with the very sticky and plastic consistence, especially for pedons PK-1 and PK-2.

The soil texture is silty clay for the higher altitude terraces (PK-1 and PK-2), and clay loam for the lower (PK-6) (Table 1). Except for
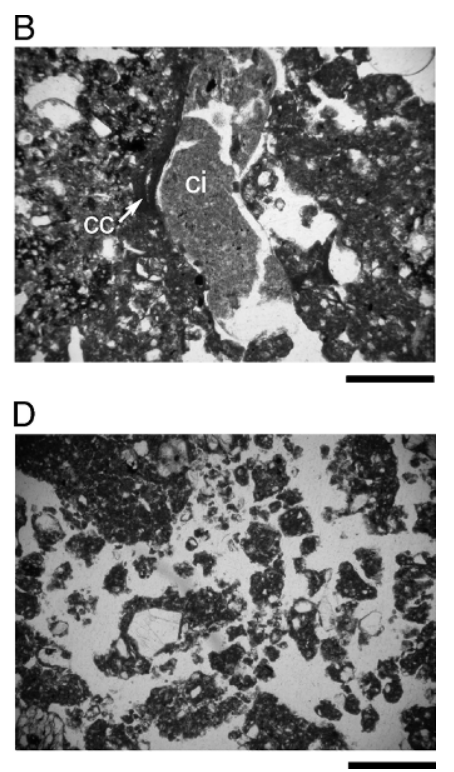

Fig. 2. Photomicrographs of selected horizons from the six pedons by plane polarized light. (A) Oxic groundmass in the Bo1 horizon of PK-1 pedon, the length of scale bar is $0.25 \mathrm{~mm}$; (B) clay coatings (cC) along the wall of root channel associated with clay infillings in the Bt3 horizon of PK-2 pedon, the length of scale bar is $0.25 \mathrm{~mm}$; (C) crescent clay coatings (cC) in the chamber of Bt1 horizon of PK-3 pedon, the length of scale bar is $0.08 \mathrm{~mm}$; (D) Angular and sub-angular microstructures in the Bw2 horizon of PK-6 pedon, the length of scale bar is $0.25 \mathrm{~mm}$. 
TABLE 2

Particle size distribution (\%) of the six soil pedons

\begin{tabular}{|c|c|c|c|c|c|c|c|c|c|}
\hline \multirow{2}{*}{ Pedon } & \multirow{2}{*}{ Horizon } & \multicolumn{3}{|c|}{ Total texture } & \multicolumn{5}{|c|}{ Sand sized class* } \\
\hline & & Sand & Silt & Clay & $\mathrm{VC}$ & $\mathrm{C}$ & M & $\mathrm{F}$ & VF \\
\hline \multirow[t]{6}{*}{ PK-1 } & A1 & 8 & 52 & 40 & 0 & 0.2 & 0.2 & 1.8 & 5.7 \\
\hline & Bo1 & 7 & 50 & 43 & 0 & 0.1 & 0.2 & 1.5 & 4.9 \\
\hline & Bo2 & 6 & 46 & 48 & 0 & 0.1 & 0.2 & 1.2 & 4.1 \\
\hline & Bo3 & 5 & 45 & 50 & 0 & 0 & 0.2 & 1.3 & 4.0 \\
\hline & Bo4 & 5 & 47 & 48 & 0 & 0 & 0.2 & 1.2 & 4.1 \\
\hline & Bo5 & 5 & 46 & 49 & 0 & 0.1 & 0.1 & 1.2 & 4.0 \\
\hline \multirow[t]{6}{*}{ PK-2 } & A & 11 & 49 & 40 & 0 & 0.2 & 0.5 & 2.4 & 6.3 \\
\hline & Bt1 & 9 & 47 & 44 & 0 & 0.4 & 0.5 & 3.2 & 5.4 \\
\hline & Bt2 & 9 & 46 & 45 & 0.1 & 0.3 & 0.5 & 1.9 & 4.9 \\
\hline & Bt3 & 8 & 45 & 47 & 1.2 & 0.6 & 0.6 & 3.6 & 5.2 \\
\hline & Bt4 & 10 & 44 & 46 & 0 & 0.3 & 0.5 & 3.5 & 5.8 \\
\hline & Bt5 & 10 & 45 & 45 & 0 & 0.5 & 0.5 & 3.6 & 6.1 \\
\hline \multirow[t]{5}{*}{ PK-3 } & A & 16 & 46 & 38 & 0.2 & 0.8 & 4.3 & 5.8 & 5.3 \\
\hline & $\mathrm{AB}$ & 19 & 42 & 39 & 0.4 & 2.3 & 2.1 & 4.4 & 10.2 \\
\hline & Bt1 & 21 & 48 & 31 & 0.2 & 4.1 & 2.8 & 5.3 & 8.4 \\
\hline & Bt2 & 20 & 39 & 41 & 0.3 & 3.0 & 5.8 & 5.3 & 5.2 \\
\hline & Bt3 & 22 & 40 & 38 & 0.3 & 3.4 & 2.7 & 5.8 & 9.7 \\
\hline \multirow[t]{4}{*}{ PK-4 } & A & 14 & 46 & 40 & 0.4 & 2.0 & 2.2 & 4.2 & 5.2 \\
\hline & Bt1 & 15 & 37 & 48 & 0.8 & 3.1 & 2.6 & 4.0 & 4.1 \\
\hline & Bt2 & 16 & 35 & 49 & 1.1 & 3.0 & 3.0 & 4.9 & 4.4 \\
\hline & Bt3 & 17 & 35 & 48 & 1.9 & 3.2 & 2.7 & 4.9 & 4.6 \\
\hline \multirow[t]{5}{*}{ PK-5 } & A & 22 & 50 & 28 & 0.1 & 1.9 & 3.1 & 5.7 & 11.1 \\
\hline & $\mathrm{AB}$ & 19 & 52 & 29 & 0.2 & 3.0 & 4.2 & 5.3 & 6.3 \\
\hline & Bt1 & 19 & 41 & 40 & 0 & 2.4 & 3.4 & 6.4 & 7.1 \\
\hline & Bt2 & 21 & 41 & 38 & 0.4 & 3.5 & 3.6 & 6.3 & 7.5 \\
\hline & $\mathrm{Bt} 3$ & 21 & 36 & 43 & 0.5 & 2.7 & 3.4 & 6.1 & 8.6 \\
\hline \multirow[t]{5}{*}{ PK-6 } & A & 27 & 44 & 29 & 1.4 & 4.7 & 4.1 & 8.0 & 9.3 \\
\hline & Bw1 & 27 & 40 & 33 & 0.7 & 3.5 & 4.0 & 9.0 & 9.6 \\
\hline & Bw2 & 27 & 34 & 39 & 1.2 & 4.6 & 4.4 & 8.7 & 8.3 \\
\hline & Bw3 & 25 & 37 & 38 & 1.3 & 4.3 & 4.0 & 8.7 & 6.7 \\
\hline & Bw4 & 25 & 39 & 36 & 1.0 & 3.5 & 3.9 & 8.9 & 7.6 \\
\hline \multicolumn{2}{|c|}{ Fluvial sediment ${ }^{\dagger}$} & 100 & 0 & 0 & 0.45 & 94.9 & 2.2 & 2.1 & 0.3 \\
\hline
\end{tabular}

${ }^{*} \mathrm{VC}=$ very coarse $(2.00-1.00 \mathrm{~mm}) ; \mathrm{C}=$ coarse $(1.00-0.50 \mathrm{~mm}) ; \mathrm{M}=$ medium $(0.50-0.25 \mathrm{~mm}) ; \mathrm{F}=$ fine $(0.25-0.10 \mathrm{~mm})$; $\mathrm{VF}=$ very fine $(0.10-0.05 \mathrm{~mm})$.

†Sediments of the Choushui river are assumed as the parental materials for the soils.

pedons PK-1 and PK-6, argillic horizon can be found in the pedons that strongly exhibit clay illuviation. For example, clay infillings have accumulated in root channels of their Bt horizons (Fig. 2B). Additionally, translocated clays are also shown as crescent coatings in the bottom of chambers (Fig. 2C). In the Bo horizons of pedon PK-1, dominant groundmass can be found as isotropically oxidic materials, with less extent of weakly stipple clay coatings (Fig. 2A). This isotropic groundmass reflects an oxic horizon but requires further identification by laboratory analysis. For pedon PK-6, trace illuvial clay is found in the sub-surface horizons but their microstructures developed well as sub-angular blocky types (Fig. 2D), thereby meeting the cambic horizon criteria as defined in Soil Taxonomy (Soil Survey Staff, 2003). Thus, the above soil morphological characteristics are consistent with the concept of a chronosequence.

\section{Physical and Chemical Properties}

Strong chemical weathering condition characterized by high air temperature and heavy rainfall in the study area has resulted in very low amounts of sand in the six pedons (Table 2). In general, the pedons display a trend of increasing sand fraction against the altitude of the terraces from pedon PK-1 to pedon PK-6. If the sand fraction is further sub-divided into five classes, the dominant classes would be fine sand and very find sand. This indicates that the parent materials 
TABLE 3

Selected chemical properties of the six pedons

\begin{tabular}{|c|c|c|c|c|c|c|c|}
\hline Pedon & Horizon & $\mathrm{OC}^{*}(\mathrm{~g} / \mathrm{kg})$ & $\mathrm{pH}$ & $\mathrm{CEC}^{\dagger}, \mathrm{cmol}(+) / \mathrm{kg}$ & $\mathrm{BSP}^{*}(\%)$ & $\mathrm{CEC} / \mathrm{clay}, \mathrm{cmol}(+) / \mathrm{kg}$ & Al saturation (\%) \\
\hline \multirow[t]{6}{*}{ PK-1 } & A & 14.4 & 4.2 & 7.3 & 11 & 18 & 64 \\
\hline & Bo1 & 4.8 & 4.5 & 7.0 & 36 & 16 & 31 \\
\hline & Bo2 & 3.2 & 4.4 & 8.4 & 26 & 16 & 36 \\
\hline & Bo3 & 3.6 & 4.4 & 7.6 & 23 & 15 & 39 \\
\hline & Bo4 & 2.4 & 4.4 & 7.8 & 35 & 16 & 28 \\
\hline & Bo5 & 2.0 & 4.5 & 7.2 & 31 & 15 & 28 \\
\hline \multirow[t]{6}{*}{ PK-2 } & A & 18.0 & 3.7 & 12 & 6 & 31 & 81 \\
\hline & Bt1 & 8.2 & 3.8 & 9.8 & 5 & 22 & 85 \\
\hline & Bt2 & 8.4 & 3.7 & 9.4 & 6 & 21 & 79 \\
\hline & $\mathrm{Bt} 3$ & 8.0 & 3.8 & 8.7 & 5 & 19 & 81 \\
\hline & Bt4 & 6.4 & 3.9 & 8.0 & 6 & 17 & 80 \\
\hline & Bt5 & 6.6 & 3.9 & 8.1 & 5 & 18 & 82 \\
\hline \multirow[t]{5}{*}{ PK-3 } & A & 17.2 & 4.1 & 10 & 12 & 25 & 78 \\
\hline & $\mathrm{AB}$ & 15.5 & 4.1 & 9.2 & 13 & 24 & 75 \\
\hline & $\mathrm{Bt} 1$ & 8.2 & 4.2 & 7.5 & 12 & 23 & 80 \\
\hline & Bt2 & 7.5 & 4.2 & 7.5 & 11 & 23 & 65 \\
\hline & Bt3 & 7.5 & 4.3 & 7.8 & 8 & 24 & 75 \\
\hline \multirow[t]{4}{*}{ PK-4 } & A & 17.5 & 4.1 & 13 & 23 & 33 & 34 \\
\hline & Bt1 & 15.0 & 4.2 & 11 & 13 & 24 & 53 \\
\hline & Bt2 & 7.7 & 4.2 & 9.3 & 14 & 20 & 56 \\
\hline & Bt3 & 7.7 & 4.3 & 9.0 & 17 & 20 & 47 \\
\hline \multirow{5}{*}{ PK-5 } & A & 15.0 & 3.9 & 9.8 & 14 & 39 & 75 \\
\hline & $\mathrm{AB}$ & 12.4 & 4.1 & 9.4 & 6 & 38 & 68 \\
\hline & Bt1 & 7.8 & 4.1 & 8.5 & 6 & 21 & 80 \\
\hline & Bt2 & 5.5 & 4.2 & 8.5 & 9 & 22 & 80 \\
\hline & Bt3 & 4.8 & 4.2 & 8.0 & 7 & 22 & 75 \\
\hline \multirow[t]{5}{*}{ PK-6 } & A & 12.8 & 3.7 & 8.7 & 15 & 30 & 56 \\
\hline & Bw1 & 11.2 & 3.9 & 8.8 & 6 & 26 & 76 \\
\hline & Bw2 & 8.4 & 3.9 & 7.4 & 6 & 20 & 81 \\
\hline & Bw3 & 9.6 & 4.0 & 8.3 & 8 & 22 & 73 \\
\hline & Bw4 & 7.6 & 4.0 & 8.2 & 10 & 22 & 69 \\
\hline
\end{tabular}

*Organic carbon.

${ }^{\dagger}$ Cation exchange capacity.

*Base saturation percentage.

of the soils were fine and highly weatherable, and thus a high rate of soil development can be expected. Among the soils, pedon PK-1 always shows the lowest amount of each sand fraction, indicating the longest time of weathering from the parent material. The variations in the vertical distribution of clay and silt also indicate a strong degree of leaching and weathering within the soil pedons. All the soils contain low organic carbon $(<20 \mathrm{~g} / \mathrm{kg})$. The $\mathrm{pH}$ and CEC values are very low, revealing relatively low clay activities associated with low base and high $\mathrm{Al}$ saturations (Table 3). When the CEC/clay data of the diagnostic sub-surface horizons are examined, pedon PK-1 has the lowest value whereas pedon PK-6 has the highest. However, the clay CEC of most $\mathrm{B}$ horizons of pedon PK-1 is within the range observed for low activity clays $(<16 \mathrm{cmol} /$ $\mathrm{kg}$ ) as defined in Soil Taxonomy (Soil Survey Staff, 2003).

Compared with DCB-extractable $\mathrm{Fe}\left(\mathrm{Fe}_{\mathrm{d}}\right)$, oxalate-extractable $\mathrm{Fe}\left(\mathrm{Fe}_{\mathrm{o}}\right)$ is relatively lower so that the ratio of oxalate and $\mathrm{DCB}$-extractable $\mathrm{Fe}$ $\left(\mathrm{Fe}_{\mathrm{o}} / \mathrm{Fe}_{\mathrm{d}}\right)$ is always less than 0.2 , indicating a low degree of pedogenic $\mathrm{Fe}$ activity (Blume and Schwertmann, 1969). The migration of pedogenic $\mathrm{Fe}$ from the eluvial horizon to the lower parts of the profile is indicated by the accumulation of $\mathrm{Fe}_{\mathrm{d}}$ in the sub-surface horizons, although the higher terrace level shows the more significant accumulation (Table 4). The $\mathrm{Al}_{d}$ concentrations do not increase as uniformly as $\mathrm{Fe}_{\mathrm{d}}$. All the terraces have nearly the same $\mathrm{Al}_{d}$ concentrations.

The activity ratio $\left(\mathrm{Fe}_{\mathrm{o}} / \mathrm{Fe}_{\mathrm{d}}\right)$ (Blume and Schwertmann, 1969) and crystallinity ratio 
TABLE 4

Chemical speciation of $\mathrm{Fe}$ and $\mathrm{Al}$ in the six soil pedons

\begin{tabular}{|c|c|c|c|c|c|c|c|c|c|}
\hline \multirow{2}{*}{ Pedon } & \multirow{2}{*}{ Horizon } & \multicolumn{2}{|c|}{ Oxalate $(\mathrm{g} / \mathrm{kg})$} & \multicolumn{2}{|c|}{ DCB $(\mathrm{g} / \mathrm{kg})$} & \multicolumn{2}{|c|}{ Total $(\mathrm{g} / \mathrm{kg})$} & \multirow{2}{*}{$\mathrm{Fe}_{\mathrm{o}} / \mathrm{Fe}_{\mathrm{d}}$} & \multirow{2}{*}{$\left(\mathrm{Fe}_{\mathrm{d}}-\mathrm{Fe}_{\mathrm{o}}\right) / \mathrm{Fe}$} \\
\hline & & $\mathrm{Fe}_{\mathrm{o}}$ & $\mathrm{Al}_{\mathrm{o}}$ & $\mathrm{Fe}_{\mathrm{d}}$ & $\mathrm{Al}_{\mathrm{d}}$ & $\mathrm{Fe}_{\mathrm{t}}$ & $\mathrm{Al}_{\mathrm{t}}$ & & \\
\hline \multirow[t]{6}{*}{ PK-1 } & A & 1.8 & 1.6 & 24.6 & 3.7 & 35.8 & 37.9 & 0.07 & 0.64 \\
\hline & Bo1 & 1.7 & 1.6 & 25.0 & 3.2 & 32.3 & 29.5 & 0.07 & 0.72 \\
\hline & Bo2 & 2.1 & 1.5 & 29.1 & 3.6 & 37.8 & 38.2 & 0.07 & 0.72 \\
\hline & Bo3 & 2.2 & 1.5 & 28.3 & 3.6 & 35.7 & 35.8 & 0.08 & 0.73 \\
\hline & Bo4 & 2.0 & 1.3 & 30.0 & 3.4 & 34.7 & 24.7 & 0.06 & 0.81 \\
\hline & Bo5 & 1.6 & 1.2 & 30.4 & 3.6 & 33.5 & 27.2 & 0.05 & 0.86 \\
\hline \multirow[t]{6}{*}{ PK-2 } & A & 2.2 & 2.1 & 27.2 & 4.0 & 36.1 & 44.8 & 0.08 & 0.69 \\
\hline & Bt1 & 2.9 & 2.1 & 26.3 & 3.6 & 32.4 & 32.6 & 0.11 & 0.72 \\
\hline & $\mathrm{Bt} 2$ & 2.3 & 2.2 & 24.7 & 3.8 & 28.2 & 32.8 & 0.09 & 0.79 \\
\hline & $\mathrm{Bt} 3$ & 2.3 & 2.2 & 27.5 & 4.1 & 34.5 & 42.7 & 0.08 & 0.73 \\
\hline & Bt4 & 2.4 & 2.3 & 28.7 & 4.2 & 34.2 & 34.4 & 0.08 & 0.77 \\
\hline & Bt5 & 4.1 & 3.3 & 31.1 & 4.5 & 37.0 & 37.3 & 0.13 & 0.73 \\
\hline \multirow[t]{5}{*}{ PK-3 } & A & 4.0 & 2.2 & 31.1 & 2.3 & 36.5 & 24.4 & 0.13 & 0.74 \\
\hline & $\mathrm{AB}$ & 4.2 & 2.5 & 26.7 & 2.3 & 38.9 & 28.7 & 0.16 & 0.58 \\
\hline & Bt1 & 4.5 & 2.5 & 34.3 & 2.6 & 36.7 & 29.5 & 0.13 & 0.81 \\
\hline & Bt2 & 4.3 & 2.3 & 34.7 & 3.7 & 36.4 & 29.4 & 0.12 & 0.84 \\
\hline & $\mathrm{Bt} 3$ & 4.5 & 2.3 & 36.7 & 1.6 & 39.1 & 28.2 & 0.12 & 0.82 \\
\hline \multirow[t]{4}{*}{ PK-4 } & A & 2.9 & 2.4 & 23.8 & 4.3 & 26.4 & 15.8 & 0.12 & 0.79 \\
\hline & Bt1 & 2.6 & 2.4 & 23.5 & 3.8 & 31.0 & 6.2 & 0.11 & 0.67 \\
\hline & Bt2 & 2.8 & 2.2 & 27.4 & 4.7 & 33.4 & 18.5 & 0.10 & 0.73 \\
\hline & Bt3 & 2.8 & 2.2 & 29.5 & 4.6 & 35.3 & 29.2 & 0.09 & 0.76 \\
\hline \multirow[t]{5}{*}{ PK-5 } & A & 4.8 & 2.5 & 31.3 & 2.3 & 41.3 & 24.1 & 0.15 & 0.64 \\
\hline & $\mathrm{AB}$ & 5.3 & 3.0 & 37.9 & 1.6 & 42.9 & 23.3 & 0.14 & 0.76 \\
\hline & Bt1 & 6.6 & 3.0 & 33.2 & 2.4 & 45.4 & 24.2 & 0.20 & 0.59 \\
\hline & Bt2 & 7.1 & 2.4 & 37.2 & 2.3 & 43.7 & 27.1 & 0.19 & 0.69 \\
\hline & Bt3 & 6.3 & 2.3 & 31.9 & 1.9 & 42.1 & 32.3 & 0.20 & 0.61 \\
\hline \multirow[t]{5}{*}{ PK-6 } & A & 1.7 & 1.6 & 16.2 & 3.0 & 29.0 & 36.4 & 0.10 & 0.50 \\
\hline & Bw1 & 2.0 & 1.8 & 17.0 & 3.3 & 29.4 & 34.9 & 0.12 & 0.51 \\
\hline & Bw2 & 2.0 & 2.2 & 18.7 & 3.8 & 33.8 & 44.4 & 0.10 & 0.50 \\
\hline & Bw3 & 1.9 & 2.2 & 18.0 & 3.8 & 33.5 & 41.5 & 0.11 & 0.48 \\
\hline & Bw4 & 2.1 & 2.2 & 18.3 & 3.9 & 33.3 & 36.5 & 0.11 & 0.49 \\
\hline
\end{tabular}

$\left(\mathrm{Fe}_{\mathrm{d}}-\mathrm{Fe}_{\mathrm{o}}\right) / \mathrm{Fe}_{\mathrm{t}}\left(\mathrm{Fe}_{\mathrm{t}}\right.$ represents total $\left.\mathrm{Fe}\right)$ (Nagatsuka, 1972) of iron have been demonstrated to assess soil development. McFadden and Hendricks (1985) showed that the activity ratio $\left(\mathrm{Fe}_{\mathrm{o}} / \mathrm{Fe}_{\mathrm{d}}\right)$ in the chronosequence of southern California was moderately high to very high (0.22-0.58) in Middle Holocene to Late Pleistocene soils and progressively decreased to less than 0.10 in older soils. Arduino et al. (1984) showed that $\left(\mathrm{Fe}_{\mathrm{d}}-\mathrm{Fe}_{\mathrm{o}}\right) / \mathrm{Fe}_{\mathrm{t}}$ of the soils in western Po Valley of northern Italy increased gradually with ages of the terraces, which range from early Middle Pleistocene to Upper Pleistocene-Holocene. Figure 3 shows the values of $\left(\mathrm{Fe}_{\mathrm{o}} / \mathrm{Fe}_{\mathrm{d}}\right)$ and $\left(\mathrm{Fe}_{\mathrm{d}}-\mathrm{Fe}_{\mathrm{o}}\right) / \mathrm{Fe}_{\mathrm{t}}$ for all the soils in the six pedons evaluated. All the data, except part of pedon PK-6, are within Nagatsuka's (1972) red soil region $\left[\mathrm{Fe}_{\mathrm{o}} / \mathrm{Fe}_{\mathrm{d}} \leq 0.4,\left(\mathrm{Fe}_{\mathrm{d}}-\right.\right.$ $\left.\left.\mathrm{Fe}_{\mathrm{o}}\right) / \mathrm{Fe}_{\mathrm{t}} \geq 0.5\right]$. The higher terrace (i.e., PK-1 and $\mathrm{PK}-2)$ is associated with lower values of
$\mathrm{Fe}_{\mathrm{o}} / \mathrm{Fe}_{\mathrm{d}}$ but higher values of $\left(\mathrm{Fe}_{\mathrm{d}}-\mathrm{Fe}_{\mathrm{o}}\right) / \mathrm{Fe}_{\mathrm{t}}$. A trend is apparent in which the crystallinity ratio of free iron gradually increases with ascending altitude (or level) of the terraces but the activity ratio decreases. This trend is similar to that obtained by Maejima et al. (2002).

\section{Clay Mineral Compositions}

Vermiculite, vermiculite-illite interstratified minerals, illite, kaolinite, quartz, and gibbsite are present in the six soils in variable quantities (Table 5). They seem very similar in mineral composition but vary in abundance. Kaolinite and illite are the predominant minerals whereas montmorillonite and chlorite are absent. The clay minerals remain relatively constant in amount with depth throughout the pedons. The XRD patterns of the clay fractions from the $\mathrm{Bt} 2$ horizon of pedon $\mathrm{PK}-1$ are presented to explain 


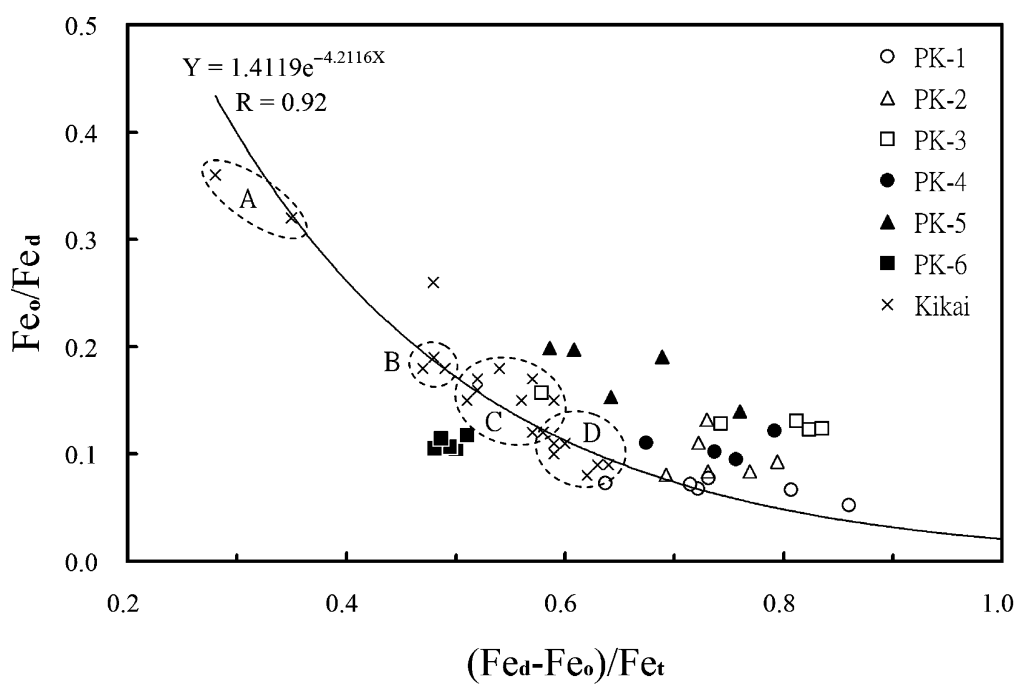

Fig. 3. The activity and crystallinity ratios of free iron oxides of all the soils. The exponential curve fits the data from Kikai island (Maejima et al., 2002). The dashed circles indicate soils ages of A (3.5-3.9 ka), B (35-40 ka), C (50-80 $k a)$, and D (100-125 ka).

the clay mineralogy of the soils (Fig. 4). Vermiculite is characterized by the $d$ value of $1.4 \mathrm{~nm}$ peak at $25^{\circ} \mathrm{C}$, collapsing to $d$ value of $1.0 \mathrm{~nm}$ when the $\mathrm{K}$-saturated clays were heated at $300{ }^{\circ} \mathrm{C}$. Vermiculite-illite interstratified minerals are characterized by the basal XRD peak intermediate between 1.0 and $1.4 \mathrm{~nm}$ for Mg-saturated clays (Sawhney, 1989). Glycerol treatment does not alter the spacings, but on $\mathrm{K}$ saturation and heating to $300{ }^{\circ} \mathrm{C}$ the layers of the vermiculite component collapse to the illite spacing resulting in a $1.0-\mathrm{nm}$ peak and a series of higher orders. The broad peaks in this range indicate the presence of vermiculite-illite interstratified minerals. The XRD patterns of $\mathrm{Mg}$-saturated clay at $25{ }^{\circ} \mathrm{C}$ indicate that illite (1.0-nm and 0.334-nm peaks), kaolinite $(0.72-\mathrm{nm}$ peak), and quartz (0.426-nm and 0.334-nm peaks) are present. Gibbsite is reconfirmed by the peak $(0.485 \mathrm{~nm})$ that disappeared when the $\mathrm{K}$-saturated clays were heated to $350{ }^{\circ} \mathrm{C}$ (Fig. 4). Weak reflections at $25{ }^{\circ} \mathrm{C}$ in all figures are present at 12.5 and 25 degrees (20), and they could contain only chlorite or kaolinite, or a mixture of the two. The $\mathrm{HCl}$ treatment without cationic saturation in this study was used to destroy the chlorite structure and to differentiate chlorite and kaolinite, which have very different structures and pedogenic occurrences, but difficulties exist when they occur in intimate mixtures. Weak reflections at $25{ }^{\circ} \mathrm{C}$ in all figures are present at 12.5 and 25 degrees $(2 \theta)$, and they could contain only chlorite or kaolinite, or a mixture of the two. However, the residual peaks at 12.5 and 25 degrees $(2 \theta)$ indicate the presence of kaolinite only, but not chlorite.

The results shown in Table 5 can be grouped into two sets that largely parallel the terrace altitude from which the pedons were collected. Pedons PK-1 and PK-2 contain higher amounts of kaolinite and gibbsite but lower amount of randomly interstratified minerals, and pedons PK-4 and PK-6 contain lower kaolinite and gibbsite but higher randomly interstratified minerals. Pedons of the first set are from the terraces at higher altitude, the second set are from the terraces at lower altitude. The presence of kaolinite and gibbsite as well as the absence of montmorillonite indicates high degrees of leaching and desilication of the soils (Arduino et al., 1984, 1986; Muhs 1982), resulting in the decrease in weatherable primary minerals content. In comparison, the interstratified minerals of vermiculite-illite as product of alteration from illite represent a weaker degree of leaching and desilication of the soils. The soils of the first set seem to have undergone stronger or longer weathering in the past and can be regarded as older in age than the others. This confirms that the terraces at higher altitude are older than those at the lower altitude.

\section{Pedogenesis and Soil Classification}

All the data indicate that the soils differ in the duration of their development in a sequence from PK-1 to PK-6. The transition from Ultisols to 
TABLE 5

Clay mineral composition of the six soil pedons

\begin{tabular}{|c|c|c|c|c|c|c|c|}
\hline Pedon & Horizon & G & $\mathrm{K}$ & $\mathrm{V}$ & V-I & I & Q \\
\hline \multirow[t]{6}{*}{ PK-1 } & A1 & +++ & +++ & + & + & ++ & ++ \\
\hline & Bo1 & ++ & ++ & + & + & +++ & ++ \\
\hline & $\mathrm{Bo} 2$ & ++ & +++ & + & + & +++ & ++ \\
\hline & Bo3 & ++ & ++ & + & + & +++ & ++ \\
\hline & Bo4 & ++ & +++ & + & + & +++ & + \\
\hline & Bo5 & ++ & +++ & + & + & +++ & + \\
\hline \multirow[t]{6}{*}{ PK-2 } & A & +++ & +++ & + & + & ++ & ++ \\
\hline & Bt1 & ++ & +++ & + & + & +++ & ++ \\
\hline & Bt2 & ++ & ++ & + & + & +++ & ++ \\
\hline & Bt3 & ++ & ++ & + & + & +++ & + \\
\hline & Bt4 & +++ & ++ & + & + & +++ & + \\
\hline & Bt5 & +++ & +++ & + & + & ++ & + \\
\hline \multirow[t]{5}{*}{ PK-3 } & A & +++ & +++ & + & + & ++ & ++ \\
\hline & $\mathrm{AB}$ & ++ & +++ & + & + & +++ & + \\
\hline & Bt1 & ++ & ++ & + & + & ++ & + \\
\hline & Bt2 & ++ & ++ & + & + & ++ & + \\
\hline & Bt3 & ++ & ++ & + & ++ & ++ & + \\
\hline \multirow[t]{4}{*}{ PK-4 } & A & ++ & +++ & + & + & +++ & + \\
\hline & Bt1 & ++ & ++ & + & ++ & +++ & + \\
\hline & Bt2 & ++ & ++ & + & ++ & ++ & + \\
\hline & $\mathrm{Bt} 3$ & ++ & ++ & + & ++ & ++ & + \\
\hline \multirow[t]{4}{*}{ PK-5 } & A & ++ & +++ & + & + & ++ & + \\
\hline & $\mathrm{AB}$ & ++ & ++ & + & ++ & +++ & + \\
\hline & Bt1 & ++ & ++ & + & + & ++ & + \\
\hline & Bt2 & ++ & ++ & + & ++ & ++ & + \\
\hline \multirow[t]{5}{*}{ PK-6 } & $\mathrm{Bt} 3$ & ++ & +++ & + & ++ & +++ & + \\
\hline & Bw1 & ++ & ++ & + & ++ & +++ & + \\
\hline & Bw2 & ++ & ++ & + & ++ & +++ & + \\
\hline & Bw3 & ++ & ++ & + & ++ & +++ & + \\
\hline & Bw4 & ++ & ++ & + & ++ & ++ & + \\
\hline
\end{tabular}

$\mathrm{I}=$ illite, $\mathrm{K}=$ kaolinite, $\mathrm{V}=$ vermiculite, $\mathrm{Q}=$ quartz, $\mathrm{G}=$ gibbsite, $\mathrm{V}-\mathrm{I}=$ interstratified minerals of vermicular-illite. +++ : $25-50 \%$; ++: 10-25\%; +: $<10 \%$.

Oxisols involves a degradation of argillic horizon (Soil Survey Staff, 2003). The groundmass, which loses clay coatings, shows isotropically oxic characteristics in the older soils studied, such as the Bo horizons of pedon PK-1 (Fig. 2A). This physical degradation may be accompanied by leaching processes and mineralogical alterations. Weathering breaks up the aluminosilicate clays during accelerated desilication, so that the reddest hues (Table 1), highest amounts of clay, and lowest amounts of sand (Table 2) can be found in pedon PK-1. On the contrary, relatively weak degrees of desilication, leaching, and physical degradation occur in the other pedons. Therefore, it suggests that the river terrace at higher altitudes has more developed soils and is older in age.

The sequence from PK-1 to PK-6 can be also identified by the soil classification results.
Except pedons PK-1 and PK-6, all the soils are classified as Ultisols in Soil Taxonomy (Soil Survey Staff, 2003). Based on morphology, clay migration, and CEC/clay data, pedon PK-1 is the oldest whose sub-surface horizons met the requirements of an oxic horizon. Therefore, pedon PK-1 is classified as Fine, mixed, hyperthermic Typic Hapludox. Pedons PK-2, PK-3, and $\mathrm{PK}-5$ are well-developed Ultisols classified as Fine, mixed, hyperthermic Typic Paleudults whereas pedon PK-4 is a Fine, mixed, hyperthermic Typic Hapludult. Pedon PK-6 is a Typic Dystrudept and is the youngest soil in the study area because no clear clay accumulation can be found in its B horizons. A similar trend in age of the soils can be observed when they are classified according to the World Reference Base (WRB) system of soil classification (ISSS Working Group WRB, 1998). Pedon PK-1 is classified as Haplic Ferralsol; pedons PK-2, PK-3, PK-4, and PK-5 are Haplic Acrisol; and pedon PK-6 is Haplic Cambisol. The surface deposits of the terraces began forming at different periods in the past and are still exposed; thus, they represent the "postincisive chronosequence" described by Vreeken (1975). This agrees with the report of Shih and Yang (1985) that the terraces of southern Pakua tableland were developed by successive river incision. The terrace in PK-1 represents the remnant of the alluvial fan deposited by the ancient Choushui River, and the sub-sequent river incision formed the other terraces on which pedons PK-2 to PK-6 developed.

\section{Age Estimation for River Terraces}

There have been studies showing that the age of soil can be estimated based on its positive relationship to the iron activity and negative relationship to iron crystallinity (Arduino et al., 1984, 1986; McFadden and Hendricks, 1985). Maejima et al. (2002) successfully estimated the age of lateritic red soils of the Minamidaito island based on Fe activity and crystallinity ratios of dated soils (from ca. 35 to $125 \mathrm{ka}$ ) from the Kikai island in southern Japan. The comparable oceanic sub-tropical climatic condition between Kikai island and Taiwan allows age estimation for the soils studied using the method of Maejima et al. (2002). The soils of the Pakua tableland exhibit a pattern in the activity and crystallinity ratios of free iron that coincides with those of soils in Kikai island (Fig. 3). The higher crystallinity ratios of pedons PK-1, PK-2, PK-3, and PK-4 indicate stronger soil development, probably with ages greater than $125 \mathrm{ka}$. 


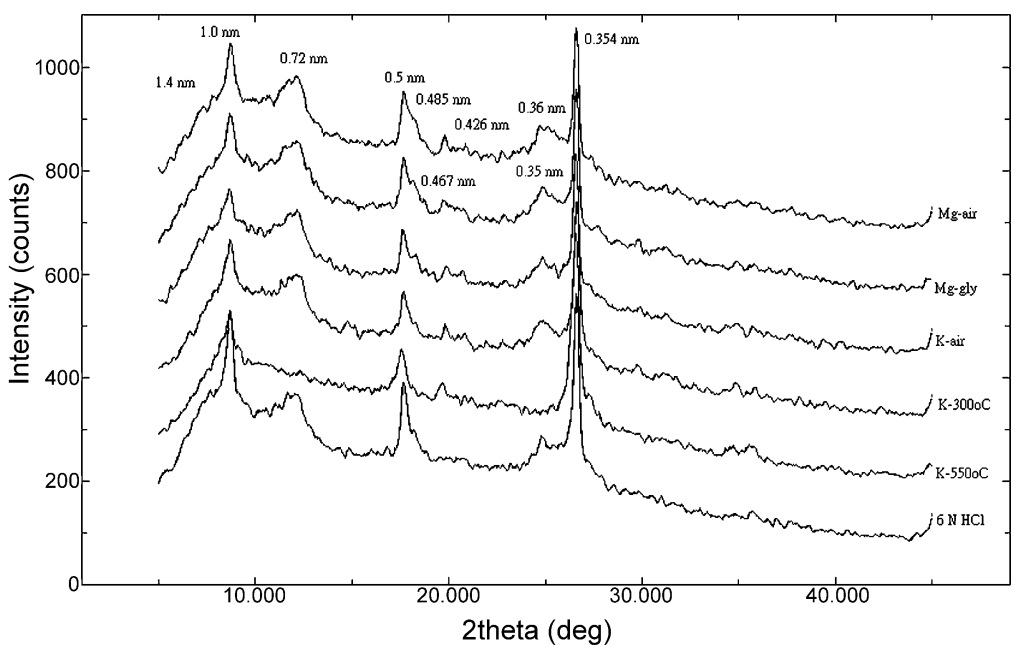

Fig. 4. XRD patterns of clay fraction in the Bo2 horizon of PK-1 pedon.

The power equation by the abovementioned authors $\left(\mathrm{Fe}_{\mathrm{d}}-\mathrm{Fe}_{\mathrm{o}}\right) / \mathrm{Fe}_{\mathrm{t}}=0.0687\left(\right.$ age $\left.^{0.1857}\right)$ gives ages of 40-400 ka from the mean values of the crystallinity ratio of the soil pedons. However, the intermixed distribution of $\left(\mathrm{Fe}_{\mathrm{d}}-\right.$ $\left.\mathrm{Fe}_{\mathrm{o}}\right) / \mathrm{Fe}_{\mathrm{t}}$ hinders individual age determination for the soils. Assuming that soil formation began shortly after each river terrace was formed, the estimated ages of the soils are relatively comparable to those of the river terraces. The age estimates based on the pedogenetic processes in this study are in agreement with the ages of the lateritic terraces in Taiwan, which based on present knowledge are older than $30 \mathrm{ka}$ (Chen and Liu, 1991; Ota et al., 2002).

\section{CONCLUSIONS}

Analyses of the soils along the chronosequence in southern Pakua tableland showed that pedogenic intensity is strongly dependent on the terrace levels with varying ages of formation. All the soils differ in the duration of their development, which can be identified by morphological, physical, and chemical properties and clay mineral compositions. They determine the degree of redness, structure and consistence development, clay migration, pedogenic $\mathrm{Fe}$ activity and crystallinity, and alteration of clay mineral. The degree of soil development increases with altitude in a sequence from PK-1 to PK-6. They form a postincisive type of soil chronosequence, which is in accord with the evolution of the geomorphic surface by successive river incision in the study area. Based on the crystallinity ratios of free iron, the soils give an estimated age of 40-400 ka for the river terraces of the Pakua tableland.

\section{ACKNOWLEDGMENTS}

The authors thank the National Science Council of the Republic of China, Taiwan, for financially supporting this research under Contract No. NSC 92-2116-M-018-002 and 922313-B-020-009. The authors also thank Dr. Victor B. Asio, Professor of Soil Science of the Institute of Tropical Ecology, Leyte State University, Philippines, for his valuable comments on the manuscript.

\section{REFERENCES}

Angelier, J. 1986. Geodynamics of Eurasia-Philippine Sea Plate boundary: Preface. Tectonophysics. 125: IX-X.

Arduino, E., E. Barberis, F. Carraro, and M. G. Forno. 1984. Estimating relative ages from ironoxide/total-iron ratios of soils in the western Po Valley, Italy. Geoderma. 33:39-52.

Arduino, E., E. Barberis, F. Marson Ajmone, E. Zanini, and M. Franchini. 1986. Iron oxides and clay minerals within profiles as indicators of soil age in northern Italy. Geoderma. 37:45-55.

Birkeland, P. W. 1984. Holocene soil chronofunctions, southern Alps, New Zealand. Geoderma. 34:115-134.

Blume, H. P., and U. Schwertmann. 1969. Genetic evaluation of profile distribution of aluminum, iron, and manganese oxides. Soil Sci. Soc. Am. Proc. 33:438-444. 
Bockheim, J. G., J. G. Marshall III, and H. M. Kelsey. 1996. Soil-forming processes and rates on uplifted marine terrace in southwestern Oregon, USA. Geoderma. 73:39-62.

Brindley, G. W. 1980. Quantitative X-ray mineral analysis of clays. In: Crystal structures of clay minerals and their X-ray identification. G. W. Brindley and G. Brown (eds.). Mineralogical Society, London, pp. 411-438.

Brown, G., and G. W. Brindley. 1980. X-ray diffraction procedures for clay mineral identification. In: Crystal structures of clay minerals and their X-ray identification. G. W. Brindley and G. Brown (eds.). Mineralogical Society, London, pp. 305-359.

Bull, W. B. 1990. Stream-terrace genesis: implications for soil development. Geomorphology. 3: 351-367.

Bullock, P., N. Fedoroff, A. Jongerius, G. Stoops, and T. Tursina. 1985. Handbook for thin section description. Waine Res. Publ., Albrighton, England, $152 \mathrm{pp}$.

Chen, P. Y. 1977. Tables of key lines in X-ray powder diffraction patterns of minerals in clays and associated rocks. Printed in the authority of the State of Indiana Bloomington, Indiana.

Chen, Y. G., and T. K. Liu. 1991. Radiocarbon dates of river terraces along the lower Tahanchi, northern Taiwan: Their tectonic and geomorphic implications. J. Geol. Soc. China. 34:337-347.

Dawson, B. S. W., J. E. Fergusson, A. S. Campbell, and E. J. B. Cutler. 1991. Depletion of first-row transition metals in a chronosequence of soils in the Reefton area of New Zealand. Geoderma. 48: 271-296.

Delcaillau, B., B. Deffontaines, L. Floissac, J. Angelier, J. Deramond, P. Souquet, H. T. Chu, and J. F. Lee. 1998. Morphotectonic evidence from lateral propagation of an active frontal fold; Pakuashan anticline, foothills of Taiwan. Geomorphology. 24:263-290.

Dorronsoro, C., and P. Alonso. 1994. chronosequence in Almar River fluvial-terrace soil. Soil Sci. Soc. Am. J. 58:910-925.

Gee, G. W., and J. W. Bauder. 1986. Particle-size analysis. In: Methods of soil analysis: Part 1, 2nd ed. A. L. Page, R. H. Miller, and D. R. Keeney (eds.). Agron. Monogr. 9. ASA and SSSA, Madison, WI, pp. 383-411.

Ho, C. S. 1988. An introduction to the geology of Taiwan explanatory text of the geologic map of Taiwan, 2nd ed. Cent. Geol. Surv., Taipei, Taiwan, $164 \mathrm{pp}$.

Huang, C. Y., P. M. Liew, M. Zhao, T. C. Chang, C. M. Kuo, M. T. Chen, C. H. Wang, and L. F. Zheng. 1997. Deep sea and lake records of the Southeast Asian paleomonsoons for the last 25 thousand years. Earth Planet. Sci. Lett. 146:59-72.

ISSS Working Group WRB, 1998. World reference bases for soil resource: Introduction. In:
J. A. Deckers, F. O. Nachtergaele, and O. C. Spaargaren (eds.), 1st ed. International Society of Soil Science, International Soil Reference and Information Centre (ISRIC), and Food and Agriculture Organization (FAO). Acco. Leuven, Belgium, 165 pp.

Jenny, H. 1941. Factors in soil formation. McGrawHill, NY, 281 pp.

$\mathrm{Ku}$, C. C. 1963. Photogeologic study of terraces in north-western Taiwan. Proc. Geol. Soc. China 6: 51-60.

Lee, J. C., C. Y. Lu, H. T. Chu, B. Delcaillau, J. Angelier, and B. Deffontaines. 1996. Active deformation and paleostressanalysis in the Pakua anticline area, western Taiwan. TAO 7:431-446.

Leigh, D. S. 1996. Soil chronosequence of Brasstown Creek, Blue Ridge Mountains, USA. Catena. 26: 99-114.

Liew, P. M., and M. L. Hsieh. 2000. Late Holocene (2 ka) sea level, river discharge and climate interrelationship in the Taiwan region. J. Asian Earth Sci. 18:499-505.

Lin, C. C. 1957. Topography of Taiwan. Publication of the Taiwan Provincial Documentary Committee, Taichung, Taiwan. 424 pp. (in Chinese).

Maejima, Y., S. Nagatsuka, and T. Higashi. 2002. Application of the crystallinity ratio of free iron oxides for dating soils developed on the raised coral reef terraces of Kikai and Minami-Daito Island, southwest Japan. Q. Res. 41:485-493.

Markewich, H. W., and M. J. Pavich. 1991. Soil chronosequence studies in temperate to subtropical, low-latitude, low-relief terrain with data from the eastern United States. Geoderma. 51:213-239.

McFadden, L. D., and D. M. Hendricks. 1985. Changes in the content and composition of pedogenic iron oxyhydroxides in a chronosequence of soils in southern California. Q. Res. 23:189-204.

McKeague, J. A., and J. H. Day. 1966. Dithionite and oxalate extractable $\mathrm{Fe}$ and $\mathrm{Al}$ as aids in differentiating various classes of soils. Can. J. Soil Sci. 46:13-22.

McLean, E. O. 1982. Soil $\mathrm{pH}$ and lime requirement. In: Methods of soil analysis: Part 2, 2nd ed. A. L. Page, R. H. Miller, and D. R. Keeney (eds.). Agron. Monogr. 9. ASA and SSSA, Madison, WI, pp. 199-224.

Mehra, O. P., and M. J. Jackson. 1960. Iron oxides removed from soils and clays by a dithionitecitrate system buffered with sodium bicarbonate. Clays Clay Miner. 7:317-327.

Muhs, D. R. 1982. A soil chronosequence on Quaternary marine terraces, San Clemente Island, California. Geoderma. 28:257-283.

Mulcahy, M. J., and H. M. Churchward. 1973. Quaternary environments and soils in Australia. Soil Sci. 116:156-169.

Nagatsuka, S. 1972. Studies on genesis and classification of soils in warm-temperate region of 
Southwest Japan: Part 3. Some features in distribution and mode of existence of free iron and aluminum oxides in the soil profile. Soil Sci. Plant Nutr. 18:147-154.

Nelson, D. W., and L. E. Sommers. 1982. Total carbon, OC, and organic matter. In: Methods of soil analysis: Part 2, 2nd ed. A. L. Page, R. H. Miller, and D. R. Keeney (eds.). Agron. Monogr. 9. ASA and SSSA, Madison, WI, pp. 539-557.

Ota, Y., B. H. Shyu, Y. G. Chen, and M. L. Hsieh. 2002. Deformation and age of fluvial terraces south of the Choushui River, central Taiwan, and their tectonic implications. West. Pac. Earth Sci. 2:251-260.

Reisenauer, H. M. 1982. Chromium. In: Methods of soil analysis: Part 2. Chemical and microbiological properties, 2nd ed. A. L. Page, R. H. Miller, and D. R. Keeney (eds.). Agron. Monogr. Vol. 9, ASA and SSSA, Madison, WI, pp. 337-346.

Rhoades, J. D. 1982. Cation exchangeable capacity. In: Methods of soil analysis: Part 2, 2nd ed. A. L. Page, R. H. Miller, and D. R. Keeney (eds.). Agron. Monogr. 9. ASA and SSSA, Madison, WI, pp. 149-157.

Sawhney, B. L. 1989. Interstratification in layer silicates. In: Minerals in soil environments. J. B. Dixon and S. B. Weed (eds.). Soil Science Society of America, Madison, WI, pp. 789-828.
Shaw, J. N., J. W. Odom, and B. F. Hajek. 2003. Soils on Quaternary terraces of the Tallapoosa River, central Alabama. Soil Sci. 168:707-717.

Shih, T. T., and G. S. Yang. 1985. The active faults and geomorphic surfaces of Pakua Tableland in Taiwan. Geogr. Res. Natl. Normal Univ. 11:173-186 (in Chinese).

Soil Survey Staff. 1993. Examination and description of soils in the field. In: Soil survey manual. Handbook No. 18. USDA-SCS, Washington, DC, pp. 56-196.

Soil Survey Staff. 2003. Keys to soil taxonomy, 9th ed., USDA-NRCS. Washington, DC.

Thomas, G. W. 1982. Exchangeable cations. In: Methods of soil analysis: Part 2, 2nd ed. A. L. Page, R. H. Miller, and D. R. Keeney (eds.). Agron. Monogr. 9. ASA and SSSA, Madison, WI, pp. 159-165.

Tsai, Y. B. 1986. Seismotectonics of Taiwan. Tectonophysics 125:17-38.

Tsai, H., and Q. C. Sung. 2003. Geomorphic evidence for an active pop-up zone associated with the Chelungpu fault in central Taiwan. Geomorphology. 56:31-47.

Vreeken, W. J. 1975. Principal kinds of chronosequences and their significance in soil history. J. Soil Sci. 26:378-394. 